are represented by university students and field-work can be carried on during vacations. For further information write to the Head of the Department of Linguistics and Nigerian Languages, University of Ibadan, Nigeria.

The Department is also publishing Research Notes with the object of making available data and research notes of members of the Department of Linguistics and Nigerian Languages and those of other people working on West African languages who care to contribute. The object is not to publish finished articles and papers, but rather word lists, texts or folk-tales, short notes, etc., on West African languages.

The first issue is now available and contains:

Ijọ Proverbs by R. A. Freemann and Kay Williamson.

Tense/Aspect Forms in Mbe by Ayo Bamgboṣe.

Two Ngwe Folk-tales by Elizabeth Dunstan.

Yala (Ikom) Notes and Pronoun Paradigms by Robert Armstrong.

A Higi Folk-tale by Carl Hoffmann.

The second issue will contain a Word List of Kofyar by Robert Netting, and the third issue will contain a Songhai Word List by Kay Williamson.

The publication will appear at least twice a year, and the cost is $\ell_{\mathrm{r}}$ or $\$ 3.00$ for the first four issues (post free). Subscriptions should be sent to the Head of the Department of Linguistics and Nigerian Languages, University of Ibadan, Ibadan, Nigeria.

\title{
'Mawazo': a new Journal from Makerere University College
}

THE first issue of Mawazo, a new international journal published by the Faculties of Arts and Social Sciences, Makerere University College, appeared in June 1967, and included the following articles:

Kenneth Kaunda-African Unity: the Role of the University.

James S. Coleman-The Resurrection of Political Economy.

Raymond Apthorpe-Nsenga Social Ideas.

Ali Mazrui-The English Language and African Nationalism.

Basil Davidson-Thoughts on Nationalism.

Peter Marris-What are Universities for?

Reginald Green-A Lament for Nigeria.

Goran Hyden-Symbols in the 1965 Tanzania Election.

Mawazo is a Kiswahili word meaning 'reflections', 'meditations', 'thoughts', and the journal will publish independent, serious and critical commentary, primarily on topics relevant to Africa, as well as the results of recent research.

\section{Writings by West Africans}

THE Institute of African Studies of Fourah Bay College, University of Sierra Leone, sponsored an exhibition of 'Writings by West Africans' jointly with the College Library and the Fourah Bay College Bookshop in April 1967. The British Council kindly lent its centre and equipment. The aim was to demonstrate not only the very remarkable increase in published writings by West Africans but also to encourage members of the public possessing unpublished manuscripts and rare, out-of-print books to place them on public display. Over 350 books currently in print were placed on exhibition, with over 500 rare books, pamphlets, and unpublished manuscripts, including mid-nineteenth-century account books, 
church and school registers, diaries, photographs, etc. Dr. Humphrey Fisher, visiting Fourah Bay College from S.O.A.S., was responsible for the Arabic section of this exhibition for which some very valuable material was gathered. A good deal of the unpublished material was donated during the exhibition by visitors who realized that they too had something worthy of display. The unpublished manuscripts and rare printed materials are being microfilmed by the College Library for historical research. A number of manuscripts have been deposited with the Library or the National Archives.

A catalogue of these materials is being prepared in two parts by Messrs. Errol Magidson and H. M. Zell: part one on unpublished and out-of-print writings and part two on published writings in print and available. Inquiries and provisional orders should be sent to the Manager, Fourah Bay College Bookshop, Freetown, Sierra Leone. (Communicated by Mr. Michael Crowder, Director, Institute of African Studies,
Fourah Bay College)

\section{Conference on Research in Dance}

African dance was discussed at a recent conference on 'Research in Dance: Problems and Possibilities', sponsored by the Committee on Research in Dance and held from 26 to 28 May at Teachers College, Columbia University, New York City. Judith Lynne Hanna of the American University, Washington D.C., gave a paper on dance field research, in which she explored the contextual study of African dance and examined the practical utility of such research for the dance teacher, the choreographer, and the performer.

\section{Bibliography on Economic Development of Nigeria, 1950-1964}

Mrs. A. O. IKe, Serials Librarian of the University of Nigeria, Nsukka, the compiler of this bibliography, has informed us that about 140 copies are still available. Prices are: ros. 6d. (Nigeria), iss. (Europe), and $\$ 2.50$ (U.S. and Canada).

\section{African Studies at the University of Mainz}

Professor Eike HaberLand has been director of the Institute of Ethnology at the University of Mainz since March 1965 . He has taken part in two expeditions to Southern Ethiopia and lectures on the cultural anthropology and history of Africa. Other members of the Institute are Dr. Erika Sulzmann, who has made five field trips to the Congo, and is now working on the sociology and political institutions, history and sacred kingship of the peoples of northwestern Congo, and Dr. Klaus Müller, who is preparing a cultural-historical study of the influence of mediterranean cultures on Africa. The Institute's future studies will concentrate mainly on Africa and it will participate in work on ethnological problems connected with the Africa mapping project inaugurated by the Deutsche Forschungsgemeinschaft.

African studies at the University of Mainz are also being carried out by Professor Dr. Eugen Rapp (Institutum Judaicum) who is translating the Bible into Twi and has recently made two field research trips to North-Eastern Nigeria to study Chado-hamitic languages. Two dictionaries on the Glawda and Yaghwatadaxa languages are in preparation. 